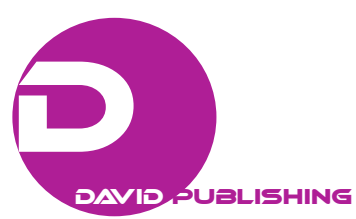

\title{
Ralph Ellison’s Literary Criticism
}

\author{
WANG Yu-kuo \\ Nanjing University of Posts and Telecommunications, Nanjing, China
}

\begin{abstract}
Ralph Ellison published many articles and speeches on various topics before and after his masterpiece Invisible Man was published. They have been collected in Shadow and Act, Going to the Territory, and The Collected Essays of Ralph Ellison (posthumously), and Shadow and Act has been selected as one of the most influential books in non-fiction with his Invisible Man in fiction which evokes more academic interests. This paper attempts to take a closer look at Ellison's literary criticism, focusing mainly on his response to the debate of "protest novel”, his reconsideration of the Negro American writings, and his analysis of how the mainstream American writers, such as Mark Twain, William Faulkner, and Ernest Hemingway, deal with the racial subjects and represent them in their creation. Owing to the strong belief in the ideals of American democracy, Ellison highlights the individuality rather than the stereotyped characteristics of the Negro people, and transcends the fixed category of black and white, for all good literature tells the same story: to be true and honest.
\end{abstract}

Keywords: protest novel, Negro American writing, racial representation

\section{Introduction}

It is widely accepted that the publication of Phillis Wheatley's verse collection Poems on Various Subjects, Religious and Moral in 1773 started the tradition of African American literature, and the New Negro Movement got some attention briefly. In 1940 Richard Wright's Native Son dramatically came into the spotlight, in which the rage and violence reflected in the novel created some sense of fear or discomfort among the white American audience. Oppositely, Ralph Ellison's Invisible Man illustrates an almost totally different representation of the rich and complex Negro experiences, won various compliments, and was awarded National Book Award in 1953. Harold Bloom has put him in the long tradition of American literature from Melville, through Mark Twain to Faulkner (Bloom, 2008, p. 9). Unfortunately, Ellison only published one novel in his lifetime, but plenty of essays, speeches, and interviews have come to the attention of his readership; The Shadow and Act (1964) and Going to the Territory (1986) have been acclaimed as equally important as his well-accepted novel Invisible Man, and he has The Shadow and Act and Invisible Man on the Modern Library's 1998 lists of the one hundred most influential books in fiction and in nonfiction during the twentieth century. The Collected Essays of Ralph Ellison (1994) includes the previous two critical books and a dozen of published or unpublished articles foregrounding his position as a social and literary critic, which arouses the readers' curiosity as to what these books of social, cultural, and literary criticism are all about, and of their relationship with his novel, while the novels published posthumously Flying Home and Other Stories (1996), Juneteenth (1999), and even his Three Days Before the

WANG Yu-kuo, Ph.D., Professor, Nanjing University of Posts and Telecommunications. 
Shooting (2010) have not met the expectations of his admirers and followers. This paper attempts to focus on Ralph Ellison's literary criticism, which can be divided into three parts. Firstly, his response to the debate about "protest novel”; secondly, his reconsideration of the Negro American writings; and thirdly, his analysis of how the mainstream American writers, such as Mark Twain, Ernest Hemingway, and William Faulkner, deal with the racial subjects and represent black people in their creations.

\section{Protest Novel? Your Protest Is Not Mine}

Although Richard Wright's Native Son has won a big applause, James Baldwin's “Everybody's Protest Novel” (1948) and "Many Thousands Gone” (1949), criticized harshly Harriet Beecher Stowe and Richard Wright for their stereotyping the characters and the social protesting in the novels, which he believes have dehumanized the Negro Americans. While Irving Howe has boasted that "The day Native Son Appeared, American culture was changed forever” (Howe, 1963, p. 152), and revealed that both James Baldwin and Ralph Ellison have betrayed the fatherly figure Richard Wright, making "the protest novel” a heated discussion/debate. Irving Howe believes that Ellison cannot help being caught up "with the idea of the Negro", and writes with "the esthetic distance" advocated by the critics of "the 'fifties" because he cannot separate the plight and protest from that experience (Howe, 1963, p. 163). Ellison believes that this kind of judgment is not fair to him and Irving Howe might have misunderstood him consciously or unconsciously for his writing on the subject of "Negro experience" does not exclude what Howe has named "plight and protest" and indicates that Irving Howe should ask himself "in what way a Negro writer will achieve personal realization (as writer) after his people shall have won their full freedom" (Ellison, 1995, p. 184). Besides, Ellison states that he should be evaluated by means of his achievements in artistic crafts rather than being measured by whether he protests or not; and no people can survive and develop by merely reacting or protesting.

According to Ellison, Irving Howe seems to believe that a man with black skin in this country is bound to protest; he cannot write, he cannot even think or breathe if he is deprived of "the protest": "be it harsh or mild, political or private, released or buried" because his literary writing undergoes constant pressures of the "sociology" of his existence, and nothing can help to remove the "pain and ferocity" with it (Ellison, 1995, pp. 158-159). In "Black Boys and Native Sons” (1963), Irving Howe blames "Ellison for abandoning the tradition of black protest literature brought to a culmination by Richard Wright in favor of a mode of writing which was excessively literary and self-indulgently individualistic” (Butler, 2004, p. 239), which echoes the previous objections from the leftists, who regard Ellison as forgetting his own black writer's responsibilities, and trying to be friended with the mainstream modernists without paying any attention to his social and political commitments in maintaining a detached social position (Butler, 2004, p. 239).

Facing Irving Howe's condescending and negative criticism, Ellison tries to balance his responses with both approval and disapproval. On the one hand, Ellison shows his agreement with Irving Howe that "protest is an element of all art, though it does not necessarily take the form of speaking for a political or social program" (Ellison, 1995, p. 183), which tends to generalize the connotations and implications of what "protest" is all about. Ellison continually expands the notion of "protest” with an innate political or ideological meaning to "a technical assault against the styles”, “or as a protest against the human condition”. He takes his own creation of Invisible Man as an example to show that one can be apparently free from "the ideological and emotional penalties 
suffered by Negroes in this country”, if he has tried his best to transform these elements into art. In addition, as a writer, just like a Blues musician, he aims at working through and even at transcending the painful conditions Blacks have encountered, without avoiding or escaping them. He also mentions that there is protest in the novel, and he puts it there, for he believes that the work of art is important in itself, and that it is a social action, which appears to the readership as if the novel itself is a protest (Ellison, 1995, p. 183).

Ellison states clearly that his arguing against or quarrelling with Irving Howe will not be taken as telling the latter how to make his literary criticism; however, as a critic, Irving Howe can comment on or judge the book in his way, and what Ellison does insist on is that he does not want to get involved with the quarrels between James Baldwin and Irving Howe about the protest novel in general, and hope for his fiction to be evaluated as a work of art rather than a text of sociology in particular. If it fails, it should fail aesthetically, "not because I did or did not fight some ideological battle” (Ellison, 1995, p. 182). Ellison was not pleased with those Negro writers complaining about racial discrimination if their books have been rejected, telling them that good art "commands attention of itself, whatever the writer's politics or point of view" (Ellison, 1995, p. 183). And if those Negro writers do not write well, it is the failure of their craft and bad writing, rather than the inadequate protest imbued in their work (Ellison, 1995, p. 183). Thus, Ellison does not refuse "protest” in the work of art, what he is displeased about is the art confined merely to social protest, and failing to represent the human condition as it is. What he stresses is that the art is as complex as life itself and should not be bound with protest against racial discrimination and social injustice.

In a 1955 interview “The Art of Fiction”, Ellison claims that there is “no dichotomy between art and protest”, and illustrates various examples of those outstanding writers and their works. For instance, Dostoevsky's Notes From Underground protests against the limitations of the 19th century rationalism, and Don Quixote, or Man's Fate, or Edipus Rex, or The Trial, to name just a few, all have protest elements, and are tempted to be against the limitation of human life itself, in which social protest and art can be aligned with each other. Otherwise, it is hard to appreciate the components and the meanings of Charles Dickens and Mark Twain. If protest is an element of all art, critics should not have a special requirement for the novels by Negro American writers, and it is surely not right to condemn those who are not "protesting" enough (Ellison, 1995, p. 212).

Ellison thinks that Irving Howe has a wrong imagination about his rejection of protest. His leaving the South does not mean that he has left the "battle", as a man of words and ideas, he has to find his identity in the world of words and ideas, no matter where he is. The last thing he can live with is a respected critic (as Irving Howe) distorting his situation in order to feel better, and he has no choice but to protest and fight back (Ellison, 1995, pp. 169-170). However, the clearest hostility is from Ernest Kaiser, whose "Negro Images in American Writing" (1967) finds fault with Ellison's placing "his work in the mainstream of American culture and who therefore has both denied his vital roots as a black person and turned a cold shoulder to African-American protest literature” (Butler, 2004, p. 241).

It is not difficult to wonder how Ellison would respond to such criticism. What he has protested against is not the "protest novel” itself, but those fixed views of or assumptions about the Negro American literature being grounded in protest. He challenges these views with a simple question that if men can make a way of life in caves and cliffs, why cannot Negroes have made a life upon the horns of the white man's dilemma? He continuously challenges those arrogant and biased views that it is hard to imagine that a people who have a strong belief in the 
idealized American Creed of equality, justice and democracy, can live and develop for over three hundred years simply by reacting? (Ellison, 1995, p. 339). To sum up, what Ellison wants to "protest" is the sociological interpretation of the rich and complex Negro experience by the write critics, and what he wishes to explore is the complex and diverse representation of Negro Americans. To those reviewers who have been blinded by the nonsense about protest, how can they really approach his and Negro American writings?

\section{Negro American Writings: His Writing Is Not Mine}

Ralph Ellison practiced and was trained as a musician, not as a literary critic, and he never tried to explore the Negro American writings systematically. In fighting against Irving Howe's accusation of his betrayal to the fatherly figure Richard Wright, Ellison elaborates on his view of Negro American literature, protecting both Richard Wright and himself from those claims and the justification of the protest novel, and focusing on the complexity and transcendence of Negro American literature. And his claims to Mark Twain, Ernest Hemingway, and William Faulkner as literary ancestors, while considering Langston Hughes and Richard Wright as literary kins again creates disagreements in the Negro community, and wins him charges ever since. This section attempts to focus on some features of Ellison's reconsideration of the Negro American literature, in which Richard Wright plays a pivotal role in his dialogue with both the tradition of the Negro American literature, and the broad context of modern Western literature.

Ellison believes that Richard Wright was quite close to the leftist, and communism did have impact over his early writings, but Wright had his own views, and began to keep a distance (for himself) even before he was sent to New York from Chicago. Though Native Son has been widely acclaimed, and Bigger Thomas has become a typical figure of the Negro, and Wright himself has become a spokesman for the so-called "a school of protest novel”, Ellison still believes that Wright is more humane and complicated than the character Bigger Thomas, because "Wright could imagine Bigger, but Bigger could not possibly imagine Richard Wright” (Ellison, 1995, p. 162). In Native Son, Bigger has been represented by Wright as a near-subhuman of the white oppression, subject to the physical environment (which seems all to him), and it seems that he has been thrown into the situation aimlessly, and can only be crammed into it. If Irving Howe insists on the authenticity of Richard Wright's creation, believing that his tone is the only authentic tone, and he is "the authentic Negro writer", then he is stripping Wright of his individuality, and creates an impression for those unfamiliar with him that "when he looks at a Negro he sees not a human being but an abstract embodiment of living hell” (Ellison, 1995, pp. 165-166). What Ellison argues is that despite the harsh realities of politics, the richness and fullness of Negro life is always there. Those who want to deny such possibilities of human richness also betray their commitment to social reality, and "Critics who do so should abandon literature for politics” (Ellison, 1995, pp. 159-160).

Ralph Ellison has been known to the readership for his book review “Richard Wright’s Blues” (1945) about the latter's new publication of Black Boy before the publication of Invisible Man (1952), which received positive remark from Lionel Trilling such as "remarkably fine", in Nation, and regarding Wright as "one of the most gifted of America's younger writers” by R. L. Duffus in New York Times; however, W. E. B. Du Bois, the most distinguished Negro American scholar and critic, regarded Richard Wright's "undeniably bleak view of black life 'unconvincing' as an autobiography. At best, Wright had offered a 'fictional autobiography', rent by its basic 'misjudgment of black folk'” (Jackson, 2002, p. 312). What Ellison wants to achieve is to rescue Wright from the 
misinterpretations. Professor Lawrence Jackson speaks highly of Ellison's talent in literary criticism, establishing him as "a superbly well educated literary critic who could hold his own against the college professors" (Jackson, 2002, p. 312), and has carried on the tradition of Hughes's and Wright's literary criticism. Moreover, Ellison has advanced a new and uncommon notion: blues lyrics specifically, one of his important contributions is to "meticulously identify Negro secular and vernacular culture as producing a profound philosophical statement" (Jackson, 2002, p. 313). This book review outlines the framework of his own future literary criticism: the redefinition of the function of the Negro writer, the application of Blues and other Negro folklore to the literary study, the focus on the black image in (Negro) American literature, and the relationship between the ideal of democracy and the literary creation.

Unlike James Baldwin, Ellison is grateful for Wright's friendship and help, especially his generosity in letting him read his manuscripts, and talking with him about how to write well. As a personal friend, Ellison was best man at his wedding. However, he has never admitted that Wright is his spiritual father. At one point Ellison states, "certainly in no sense I recognize - nor did he pretend to be", and there is no need to attack the limitations of his vision as well, for though Ellison was impressed by what Wright had achieved, if what he writes has been implicit criticisms of Wright's, it is because all novels commence a dialogue, forming an argument over the nature of reality with each other. That's how literature develops and matures. If Baldwin finds that Wright is a lion in his path, he is not Ellison's lion, because the latter is older and familiar with quite different lions in quite different paths: "I simply stepped around him”(Ellison, 1995, p. 164).

If Baldwin believes that one can only write out of his own experience, Ellison believes that one's experience should be perceived and understood by one's self-reflection, by one's conversation with the previous writers and texts. Thus, he mentions the predetermined relatives and the chosen ancestors on different occasions. He recalls that on his second day in Harlem, he got Man's Fate and Days of Wrath by French writer Andre Malraux from Langston Hughes, and "it is this fortuitous circumstance which led to my selecting Malraux as a literary 'ancestor', whom, unlike a relative, the artist is permitted to choose” (Ellison, 1995, p. 205). Before the end of his article "The World and the Jug”, Ellison addresses Irving Howe directly that he has no objections of being put together with Richard Wright if they are not estimated upon the common racial identity, but upon the qualities of what their writings have achieved. No matter whether Irving Howe likes it or not, since he had read many modern writers in Tuskegee and had benefited a lot from their writings before he meets Richard Wright in New York, Ellison points out that if he cannot choose Richard Wright and Langston Hughes as his relatives, he wants to choose Hemingway, Eliot, Malraux, Dostoevsky, and Faulkner as his literary ancestors (Ellison, 1995, p. 185).

Robert G. O’Meally summarizes Ellison's relationship with Hemingway and Faulkner, for he likes what Hemingway appreciates in the world, such as weather, guns, dogs, horses, love and hate, whereas Wright is too driven or deprived to know; and exploring a bit further, it is quite easy to hear a voice in Ellison's fiction as deeply southern as Faulkner's, which is rich and quick with southern lies (O’Meally, 2004, p. 150).

The big mistake Irving Howe has made is that he sees racial segregation as an opaque steel jug with Negroes inside waiting for some black messiah to blow the cork and save them, and Wright is the Messiah and the Savior to him. He cannot understand that no matter how strict the segregation is, socially or politically, Negro people are free to imagine, "by their individual aspiration, insight, energy and will” and to achieve their freedom. Ellison remembers clearly that when he was in Macon Country, Alabama, he began to read Karl Marx, Sigmund Freud, T. 
S. Eliot, Ezra Pound, Gertrude Stein, and Ernest Hemingway; though they seldom mention the Negro people, they are able to free me from the segregated idea, that's to say, that Ellison is not freed by the "propagandists" but by "composers, novelists, and poets who spoke to me of more interesting and freer ways of life". In this way, Ellison as well as Baldwin and Wright, are able to free themselves by means of imagination and create their own literary world (Ellison, 1995, pp. 163-164).

Richard Wright once joined the left-wing club, and was a follower of communism and Marxism. The social and physical situation and environment were stressed in his writings which contributed to the shaping of the characters, and the determination of their stories. In contrast to Irving Howe's and other critics' focus on the determination of the social situation, and the function of protest in Wright's writings, Ellison reminds the readers to notice a new element ignored by many people, the Blues culture in Wright's Black Boy. He thinks that the whole book is filled with blues-tempered echoes of railroad trains, the names of the Southern towns and cities, "estrangements, fights and flights, deaths and disappointments, charged with physical and spiritual hungers and pain". Ellison indicates that it is just like a blues sung by Bessie Smith, "its lyrical prose evokes the paradoxical, almost surreal image of a black boy singing lustily as he probes his own grievous wound” (Ellison, 1995, p. 130). Thus, he brings forward a new approach to the interpretation of the Negro fiction, which carries out what Alain Locke and Sterling Brown have both advocated in their introduction, and paves the way for the new generation in the 1960s to follow. The essence of the blues is,

....an impulse to keep the painful details and episodes of a brutal experience alive in one's aching consciousness, to finger its jagged grain, and to transcend it, not by the consolation of philosophy but by squeezing from it a near-tragic, near-comic lyricism. As a form, the blues is an autobiographical chronicle of personal catastrophe expressed lyrically. (Ellison, 1995, p. 129)

Why is the blues so important to Richard Wright and to other Negro American writers? The music genre breaks through the boundary of the social and ideological "protest", calls for a positive rather than a negative response to the hostile environment, and tells a truer and more honest story of the Negro people not only for their survival but also for their endurance and prosperity in the new continent. Therefore, at the end of his article "Richard Wright's Blues”, Ellison reveals the attraction of it, "that they at once express both the agony of life and the possibility of conquering it through sheer toughness of spirit” (Ellison,1995, p. 143). Black Boy does not provide a solution, offers no scapegoat but the self, but has depicted the social and political actions just like blues. Ellison states,

In this lies Wright's most important achievement: he has converted the American Negro impulse toward self-annihilation and "going-under-ground" into a will to confront the world, to evaluate his experience honestly and throw his findings unashamedly into the guilty conscience of America. (Ellison, 1995, p. 144)

For Ellison knows it quite well that despite the strict segregation in the south, the Negro people do not live in a vacuum and have developed their own folk culture with their pious belief, the energetic black music and dancing, and in close contact with the soil, nature, and the industrialized Western civilization. Those who want to conceptualize their lives in abstract and stereotyped patterns will find that the simplicity and primitivism of their lives embody the diversity and complexity.

Ellison's tries to go beyond the category of sociology in Negro creation and criticism, and has helped to free 
Wright from the blame and criticism; however, it also makes himself stand out. His insistence on individual artistic freedom highlights his essay “The World and the Jug” as an open letter, responding to Irving Howe’s unfair treatment of him and James Baldwin, and can be read as "a public declaration of imaginative independence” (Porter, 2001, p. 128). For he can live with the reduction imposed by unjust laws and customs; however, he wants to fight back against that reduction by ideas, whether they are openly hostile or neutrally "objective". Ellison strongly believes that a true novel arises out of an impulse to celebrate human life, and it is ritualistic and ceremonial at its core, no matter how pessimistic and bitter it might be. He states, "Thus they would preserve as they destroy, affirm as they reject” (Ellison, 1995, pp. 161-162). Richard Wright reads and imagines himself a new world in his Jim Crow hometown Mississippi, and other Negro writers advance in the same way. Based on this experience, it is easy to follow the idea that reading is equally important as one's experience, and a wild imagination and a strong will overshadows the crude social environment to artistic creators.

\section{The Black Image: Your Depiction Is Closer to Mine}

Owing to the racial discrimination in the long history of the United States, the Negro has been randomly stereotyped and their creative writings have been categorized in the dominant American literature and culture. This sections tries to illustrate Ellison's understanding and interpretation about the reflection of black images in the great classical American writers, for instance, Mark Twain, Ernest Hemingway, and William Faulkner. Their delineations/depictions of the Negro people inform not only about the subject but the creator as well.

Displeased with the sociological category of the Negro people and the social-oriented study of Negro American literature, Ellison attempts to focus on the value of the Negro individuals, especially their social experiences, perceptions, and artistic representations. He knows quite well that the white society tries hard to keep the Negro from being individuals, and likes to take a special issue as a whole representative of the ethnic group. Their double standards of criticism have aroused the attention of those sensitive writers and creators, for "A writer writes out of his own family background, out of his own immediate community, during his formative period. And he writes out of his own talent and his own individual vision”, and should be treated individually (Ellison, 1995, pp. 393-394).

In the study of black image, Sterling Brown has conducted a pioneering job, and published The Negro in American Fiction (1937). Prior to this, Alain Locke had put forward the idea of "New Negro" in 1925, and W. E. B. Du Bois the idea of "Veil" in 1903. However, Ellison cares more about the black images created by the White writers, especially those by Mark Twain, Ernest Hemingway, and William Faulkner. When considering the 19th century great novels, Ellison lists Moby-Dick and Huckleberry Finn as representatives, and asserts that

One function of serious literature is to deal with the moral core of a given society. Well, in the United States the Negro and his status have always stood for that moral concern. He symbolizes among other things the human and social possibility of equality. (Ellison, 1995, p. 223)

The great dilemma of morality in Huckleberry Finn is how to deal with Jim, the Negro slave. When Hemingway mentions that "All modern American literature comes from one book by Mark Twain called Huckleberry Finn... it’s the best book we’ve had. All American writing comes from that” (Ellison, 1995, p. 718). It is quite significant for Hemingway to stress its importance, but Ellison also reminds readers to be aware of the reduction that Hemingway has made about this novel. For if readers accept what Hemingway suggests to "stop 
reading at the point where Jim is stolen from Huck and Tom Sawyer because from that point on it is cheating” (Ellison, 1995, pp. 718-719), they will find that Hemingway either turns a blind eye to the moral point of the novel or is unable to believe in the moral necessity that Huck must attempt to get Jim free. As Ellison has correctly proposed, "Without this attempt Huckleberry Finn becomes the simple boy's book that many would rather it be, a fantasy born of pure delight and not really serious at all” (Ellison, 1995, pp. 718-719). It is easy to recognize that Ellison pays more attention to the moral implication embodied in the novel, and overlooks the specific image of the Negro slave. What he values most is what Mark Twain attempts to achieve in the realm of imagination, if he cannot solve the social problem, or let the black slave Jim and the white boy Huck enjoy the social equality in reality, he can at least put them together afloat on the same raft, and combine the actual and the ideal in his literary world.

Mark Twain is not alone involved in various forms of "rebellion", for the contradiction between the actualities and the noble ideals generated a sense of guilt from the very beginning, and "the American novel at its best has always been concerned with this basic moral predicament”, and it may become understated or explicitly undergrounded, but it does not disappear completely. Richard Wright follows the steps of the predecessors and William Faulkner represents the moral and political problems the Negro in the South lives with daily. Daisy in The Sound and the Fury increasingly becomes the moral center of the white family by caring about almost all of the family members, leading the idiot to God symbolically, because Faulkner makes us aware of the contradictory phenomena: The slaves are often more serious than their masters and pious Christians, and closer to the essence of the aristocratic ideal; the hero in The Bear has a strong belief that "the land itself had been cursed by slavery, and that the only way for him to escape the curse was to relinquish the land” (Ellison, 1995, p. 721). In Intruder in the Dust, Faulkner takes the moral dilemma left by Mark Twain in Huckleberry Finn, and changes the format of Huck's trying to free Jim from slavery with the Negro adult Lucas Beauchamp's “ascendency in his mature dignity over the youthful Mallison and refuses to lower himself in the comic duel of status forced on him by the white boy whose life he has saved” (Ellison, 1995, pp. 104-105), and changes the Negro's caste status sanctioned by the white Southern tradition. In this sense, Faulkner tells a truer and more honest story not only about the relationship between the Negro and the white, but about our human conditions. Therefore, Ellison believes that "If you would find the imaginative equivalents of certain civil rights figures in American writing-Rosa Parks and James Meredith, say—you don’t go to most fiction by Negroes, but to Faulkner” (Ellison, 1995, p. 750).

Compared with those aggressively anti-Negro southern writers, Faulkner has a mixed attitude towards the Negroes, he presents both "the bad nigger" and "the good nigger”, which embodies most of the relationships of our concern: "the social and the personal, the moral and the technical, the nineteenth-century emphasis upon morality and the modern accent upon personal myth” (Ellison, 1995, p. 97). Most important of all, Faulkner has taken the great responsibilities of American prose after Mark Twain. As a Negro, Ellison is more likely to be attracted by those writers who do care about the condition of American democracy, and projects imaginatively the conflicts of the sacred principles of the Constitution and the Bill of Rights with the practical exigencies of human greed and fear, hate and love. Ellison indicates that

Whatever they thought of my people per se, in their imaginative economy the Negro symbolized both the man lowest down and the mysterious, underground aspect of human personality. In a sense the Negro was the gauge of the human condition as it waxed and waned in our democracy. (Ellison, 1995, p. 153) 
Ellison's assessment of Faulkner's portraiture of the Negro is rooted in his belief that literature should help readers understand their situation, and it is not necessary to describe the Negro directly in order to give them insights into their own predicament, because "all literature that's worthy of the name, is to remind us of our common humanity and the cost of that humanity. This is the abiding theme of great literature” (Ellison, 1995, p. 536). Hemingway is another good example whom Ellison values most for this reason. Compared with Faulkner's “endurance”, Hemingway's definition of courage, "grace under pressure”, seems mere "swagger”, and what Ellison wants to focus on is not Hemingway's manipulation of Negro humanity to fit his own version of the Southern myth, or his less direct depiction of American Negroes, but the effective metaphor represented in his writings. If Mark Twain takes a historical perspective to handle the Negro, and Faulkner presents them from both sides, Hemingway just ignores the dramatic and symbolic possibilities presented by this theme. Though Hemingway seldom depicts Negroes and they are not the types Negroes prefer to encounter in fiction, but he offers "a valid metaphor not only for the predicament of young whites, but as a metaphor for the post-World War I period generally. Seen in this inclusive light, he tells us a hell of a lot about the way Negroes were feeling and acting” (Ellison, 1995, pp. 749-750). What Hemingway has written of the twenties, the thirties, and even of the forties has called forth some basic, and deeply felt modes and attitudes within his characters which closely approximate certain basic attitudes held by many Negro about their position in American society, and about their sense of the human predicament (Ellison, 1995, pp. 748-749). While the Negro writers, who should be more aware of these, have not portrayed truer pictures of them.

Ellison pays more attention to quality rather than quantity, his concern in regard to the Negro issue is not whether you have pictured the black image directly, or how many Negroes appear in your fiction, but the attitudes of your characters towards life, those athletes, expatriates, bullfighters, traumatized soldiers, and impotent idealists encounter what the representative group of the Negro American — the jazz musicians have lived by, and the abstract and much-betrayed ideals of that society have been replaced with "more physical values of eating, drinking, copulating, loyalty to friends and dedication to the discipline and values of their art” (Ellison, 1995, p. 749). That's to say, the value of literature to the Negro people should not be confined to whether they have told a Negro story or had their images presented, but the insight into their predicament and complex situations. In recalling the influence of Hemingway's Death in the Afternoon, Ellison notices that knowing what you really feel, rather than what you are supposed to feel or have been taught to feel, is equally important to putting down what really happens in action. Because as an exiled stranger in his own land, the Negro has been imbued with what they should feel and how they should respond rather than what they really feel and respond almost all the time (Ellison, 1995, p. 58).

In answering why Hemingway is more important to him than Wright, Ellison illustrates various reasons, and the most important is that Hemingway knows quite well the difference between politics and art, the spirit beyond the tragic which is closer to the feeling of the blues, and "he was in many ways the true father-as-artist of so many of us who came to writing during the late thirties” (Ellison, 1995, pp. 185-186). Ellison stresses his own artistic creation in fiction, while leaving his political point of view in his essays, book reviews might be a good response to Hemingway's example. Ellison's disappointment with the understatement of Hemingway's morality by his followers reveals his main concern, for Ellison reads Hemingway, and finds that, 
...he affirms the old American values by the eloquence of his denial, makes his moral point by stating explicitly that he does not believe in morality, achieves his eloquence through denying eloquence, and is most moral when he denies the validity of a national morality which the nation has not bothered to live up to since the Civil War. (Ellison, 1995, p. 708)

And Ellison's preference to Hemingway and his writings might provoke disagreements in the study of black image, and leads to various discussions concerning his own cultural identification.

\section{Conclusion}

Though it is arguable to say that Ellison's non-fiction, especially his literary criticism is as equally important as his fiction, one point is clear that this author is one of the most celebrated novelists in the 20th century, and one of the major American intellectuals of the middle and later twentieth century. His focus on the value and function of literature, and for his clinging to the ideal of American democracy, which expands our vision of not only America, but of the world, has predicted the developing trend in African American literature, which "no longer has to be obsessed with the burden or expectation of political protest or special pleading for the humanity of the race or the worth of its history and culture as it had to in the past” (Norris, 2014, p. 4). Ronald A. T. Judy states in retrospect that many of Ellison's essays and occasional papers exhibit "a subtle and rigorous mind, whose attempts to theorize America in relation to the Negro and literary expression offer valuable insight into how we might understand the current association of 'America' with what is at times now called 'globality'” (Judy, 2003, p. 2).

In a broad context of New Criticism from the 1950s in the United States, focusing on close readings and the crafting strategies, Ellison's literary criticism engages the cultural and ideological situation. This noted author argues on topics pertaining to racial issues based on the sacred principles of the American Constitution and the ideal of democracy, and his combination of aesthetics and politics, which calls for some negative feedback from his own ethnic group. However, it has been proved with time that of all American writers, Ellison "most forcefully took up the challenge of thinking beyond the imprisoning reductiveness of race and of liberating the cosmopolitan energies of democracy", and he has been ahead of us, putting art and utopian thinking aligned (Posnock, 2005, p. 1).

\section{References}

Bloom, H. (2008). Ralph Ellison's Invisible Man. New York: Infobase Publishing.

Butler, R. J. (2004). Probing the lower frequencies: Fifty years of Ellison criticism. In Steven C. Tracy (Ed.), A historical guide to Ralph Ellison (pp. 233-260). New York: Oxford University Press.

Ellison, R. (1995). The collected essays of Ralph Ellison. J. F. Callahan, (Ed.). New York: The Modern Library.

Howe, I. (1963). Black boys and native sons. In J. F. Trimmer (Ed.), A casebook on Ralph Ellison's Invisible Man (pp. 150-169). New York: T. Y. Crowell.

Jackson, L. (2002). Ralph Ellison: Emergence of genius. Athens \& London: The University of Georgia Press.

Judy, R. A. T. (2003). Ralph Ellison-The next fifty years. Boundary 2, 30(2), 1-4.

Norris, K. (Ed.). (2014). Street lit: Representing the urban landscape. Lanham·Toronto·Plymouth, UK: The Scarecrow Press, Inc. O’Meally, R. G. (2004). The rules of magic: Hemingway as Ellison’s “Ancestor”. In J. F. Callahan (Ed.), Ralph Ellison's Invisible Man: A casebook (pp. 149-187). New York: Oxford University Press.

Porter, H. A. (2001). Jazz country: Ralph Ellison in America. Iowa City: University of Iowa Press.

Posnock, R. (Ed.). (2005). The Cambridge companion to Ralph Ellison. New York: Cambridge University Press. 